\title{
All or None? A Four-Country Experiment on How the Threat of Terrorism Affects Support for
}

Counterterrorism Measures *

\author{
Øyvind Bugge Solheim ${ }^{\dagger}$
}

\begin{abstract}
Terrorism is tightly connected to the Muslim minority in the West, and this could lead to counterterrorism measures targeting Muslims specifically. This paper uses a unique survey experiment fielded in the US, France, Finland, and Norway to study the levels of support for targeting groups that vary in both their majority versus minority status and in their connection to terrorism. Threatening news stories are used to investigate whether or not the level of support is affected by rightwing extremist and Islamist terrorism. Finally, the moderating effect of attitudes toward immigration is studied. People support counterterrorism measures that target threatening groups (Islamists and right-wing extremists) more than those that do not (Muslims), but this is not the case for those people who are against immigration. When people read threatening news stories, there is an increase in support for counterterrorism measures in general, even measures that target groups unrelated to the stories.
\end{abstract}

\footnotetext{
*Paper presented at the MPSA 76th Annual Conference Chicago, April 5-8, 2018

${ }^{\dagger} \mathrm{PhD}$ Candidate, Institute for Social Research, Oslo, Norway. E-mail: o.b.solheim@socialresearch.no
} 


\section{Introduction}

Terrorism poses a crucial dilemma for democracies. Terrorists exploit the open characteristic of democratic societies in order to carry out acts of terrorism. The extreme nature of terrorist violence may lead the government to counter terrorism with similarly extreme means - something that may threaten civil liberties as well as the liberal and open characteristic of such societies (Wilkinson, 2006). Nevertheless, democracies are thought to excel at counterterrorism measures when compared to autocracies because their strong commitment to civil liberties serves as a bulwark against resorting to illiberal and counterproductive security measures (Abrahms, 2007). Recent Islamic terrorist attacks, however, are perpetrated under conditions that may be more conducive to overreactions than earlier waves of such attacks. Western countries have both visible Muslim minorities and a salient immigration debate. Because people tend to be more supportive of measures that target groups other than their own (Viscusi \& Zeckhauser, 2003), the terrorist threat may make people more supportive of policies that directly target the Muslim minority. Support for counterterrorism measures seems to increase when people perceive a threat (Davis \& Silver, 2004; Huddy, Feldman, Taber, \& Lahav, 2005), possibly because threats increase an individual's need for protection, and because threats reduce support for civil liberties (Albertson \& Gadarian, 2015; Marcus, Sullivan, TheissMorse, \& Wood, 1995). This paper asks how the threat of terrorism affects support for counterterrorism measures that target different groups; more specifically, how this support is dependent on the threatening group and the individuals' prior attitudes toward immigration.

This paper uses a survey experiment fielded in the US, France, Finland, and Norway to study the effects of the threat of terrorism on support for counterterrorism measures. 
The experiment presents respondents with news stories reporting on an imminent terrorist threat and then asks about their support for counterterrorism measures. Because both the group causing the threat and the group being targeted by the counterterrorism measures are randomized in the experiment, it is possible to study how the threat of terrorism affects groups that are both related and unrelated to terrorism. In addition, the experiment asks about both Muslims and Islamists - two groups that differ in the level of threat that they represent and in their adherence to democracy. This facilitates the comparison of the baseline support for measures targeting each group and how the terrorist threat affects these possible group differences. This experiment gives insight into how the threat of terrorism affects attitudes created by that terrorism toward a central dilemma in democracies: the dilemma between civil liberties and security measures.

This dilemma between civil liberties and security measures is central in choosing counterterrorism measures. The battle for the hearts and minds of the people is important for winning the fight against terrorists (Schuurman, 2013)), and creating counterproductive overreactions by security forces is, at times, the goal of terrorists (Wilkinson, 2006). Countries that respect civil liberties have been found to suffer less from terrorism than other countries (Walsh \& Piazza, 2010; Piazza \& Walsh, 2010)), and it is especially the repression of minorities that increases terrorism (Piazza, 2017). Indeed, Abrahms (2007) argues that democracies are especially effective at countering terrorism because their strong support for civil liberties serves as a bulwark against overreactions that may give legitimacy to the terrorists. While democratic publics support civil liberties in an abstract sense, they are less inclined to support the liberties of specific groups, and groups that are perceived as threatening or undemocratic are not tolerated to the same extent as others (Marcus et al., 1995; Sniderman, Petersen, Slothuus, \& Stubager, 2014). It is 
unclear if this support for civil liberties does, in fact, protect democracies from implementing illiberal policies targeting minorities such as Muslims. Research has found that the threat of terrorism is associated with higher levels of support for abstract counterterrorism measures and for measures targeting more specific groups related to terrorism (Davis \& Silver, 2004; Huddy et al., 2005; Huddy, Feldman, \& Weber, 2007). The effects of the terrorist threat across different groups has not been compared or studied to determine if such a threat only affects attitudes toward related groups. The following section presents the extant research on support for civil liberties and support for counterterrorism measures. Special emphasis is placed on both the threat and importance of the group background of both the groups carrying out attacks and the groups targeted by the counterterrorism measures. The survey experiment and data are then presented, followed by the results from the analyses. Finally, the findings and their implications are discussed.

\section{Threat and support for security measures}

Terrorism has been found to increase support for counterterrorism measures. People who feel threatened by terrorism support counterterrorism measures over civil liberties to a higher extent than others (Davis \& Silver, 2004; Huddy et al., 2005; Huddy et al., 2007). ${ }^{1}$ This correlation is supported by a study of the effects of the $7 / 7$ attacks in London (Bozzoli \& Müller, 2011) and by studies using experimentally induced threats (Haider-Markel, Joslyn, \& Al-Baghal, 2006; Lahav \& Courtemanche, 2012; Malhotra \& Popp, 2012). So far, most research studying the connection between terrorist threats and counterterrorism measures asks about either the abstract and general measures or

\footnotetext{
1 This is indeed the case for crime in general as well, see Mondak and Hurwitz (2012).
} 
the targeting of a specific group, such as Arabs or Muslims. It is yet unclear if the higher support when under threat is driven by a higher general support for security measures, if it is an increase in the support for targeting specific groups, or both. ${ }^{2}$ In addition, while the political cleavage on immigration seems to be more important by the day, there are few studies on how attitudes toward immigration moderate the effects of a given threat. Below, the extant research is discussed, and this discussion leads to four hypotheses. There are theoretical reasons to expect that the terrorist threat has both a general effect and a specific effect on attitudes toward the groups creating the threat. Moreover, it is reasoned that there are baseline differences in support for targeting different groups and the support for targeting different groups being connected to attitudes toward immigration and that the effects may differ between the four countries.

Research on the political effects of anxiety has found that people change their policy preferences when they feel threatened. Albertson and Gadarian (2015, p. 5) show that threats lead to anxiety and that anxious individuals support security policies to a higher extent than others. However, this support is contingent on the interpretation of the policies as enhancing security. When a policy is not perceived as threat protection, it is not supported to a higher extent by anxious individuals. An experiment on support for counterterrorism measures by Haider-Markel et al. (2006) supports this finding. Reminding people of the terrorist threat increases support for protective policies, but this is only the case for policies that are directly connected to the type of terrorism people are reminded of. ${ }^{3}$ Following this logic, the threat of terrorism could be expected to in-

2 Terrorism has a negative effect on attitudes toward out-groups, and Echebarria-Echabe and Fernández-Guede (2006) even find terrorism to affect attitudes toward unrelated out-groups such as Jews after the March 112004 attacks in Madrid (see also Das, Bushman, Bezemer, Kerkhof, \& Vermeulen, 2009; Merolla \& Zechmeister, 2009, ch. 3, for similar findings).

${ }^{3}$ Finseraas and Listhaug (2013) also find that the Mumbai terrorist attacks increased perceptions of 
crease support for targeting the relevant terrorist groups and possibly increase support for counterterrorism measures in general. This leads to the first hypothesis:

Hypothesis 1 The threat of terrorism increases support for counterterrorism measures in general (a) and more specifically for measures targeting the group creating the threat (b).

Support for counterterrorism measures is contingent on support for civil liberties. Combating terrorism is difficult and fundamental civil liberties are often threatened by counterterrorism measures. Support for civil liberties may accordingly be a bulwark against illiberal and undemocratic measures. Literature on political tolerance has been preoccupied with differences in the support for civil liberties of different groups since Stouffer's seminal study (1955). Studies find broad support for abstract civil liberties, but people are more restrictive when these liberties are applied to specific groups (Petersen, Slothuus, Stubager, \& Togeby, 2011; Sniderman et al., 2014; Steen-Johnsen, Fladmoe, \& Midtbøen, 2016). Two explanations have been proposed for these group-based differences in tolerance: one is based on the effects of anxiety and the other is based on the target group's adherence to democracy.

Marcus et al. (1995) argue that people become anxious when asked about groups they perceive as threatening. Anxiety decreases reliance on prior convictions (Marcus, Neuman, \& MacKuen, 2000), and anxious people reevaluate their support for the civil liberties of the threatening groups. They come to a different conclusion than when asked about their support for civil liberties in an abstract sense. Assuming that terrorism threat from terrorism in Europe, but that the attacks did not increase support for security measures. This may be interpreted as a consequence of the lack of relevance of the attacks for domestic security policies. 
increases anxiety, one may expect that terrorism reduces support for civil liberties in general. A reduction in support for civil liberties could in turn mean higher support for counterterrorism measures in general (Davis \& Silver, 2004) and increased support for targeting unrelated groups. Sniderman et al. (2014) and Petersen et al. (2011) find differences in tolerance that follow the same pattern, but their interpretation is different. Rather than pointing to anxiety, they argue that tolerance is dependent on a group's acceptance of "the rules of the larger society" (Sniderman et al., 2014, p. 145). They find that while Muslims are seen as accepting the rules and are thus categorized as "out of the mainstream", Islamic fundamentalists are not seen as accepting these rules and are seen as transgressive and undemocratic. The civil liberties of Muslims are thus supported to a larger extent than those of Islamic fundamentalists. To support this argument, Sniderman et al. (2014) show similar patterns of support for the civil liberties of other pairs of groups where one is transgressive and the other is not.

Few studies exist that research the support for security measures targeting different groups. Christensen and Aars (2017) find that Norwegians support surveillance of threatening groups such as Islamic fundamentalists more than they support surveillance of comparatively democratic groups such as a Muslim congregation. Therefore, support for surveillance seems to be lower for groups granted extensive civil liberties, according to Sniderman et al. (2014) and Marcus et al. (1995). Piazza (2015), however, did not find this expected pattern. He asked people about what the police should do with the perpetrators of a terrorist attack in a survey experiment and did not find higher support for the prolonged detention of Islamic fundamentalists compared to Muslims. However, in this experiment, both groups are described as having already perpetrated a terrorist attack. Accordingly, both groups are presented as threatening and violating core demo- 
cratic norms, and the difference in effects may be explained by the experiment itself. These results could indicate that the terrorist threat should reduce the differences in support for civil liberties for Muslims relative to Islamic fundamentalists. Still, this was not the case in the study of the reactions to the caricature crisis in Denmark (Sniderman et al., 2014). Accordingly, it may be the case that people perceive democratic groups as more transgressive when reminded of the terrorist threat from members of the group. This leads to the second hypothesis:

Hypothesis 2 There is higher support for counterterrorism measures targeting transgressive or threatening groups than for measures targeting other, more democratic, groups (a). Threats increase the support for targeting democratic groups, thereby reducing the difference between the two types of groups (b).

The two most common types of terrorists, Islamic and right-wing extremist terrorists, are both connected to the salient political cleavage on immigration. The support for targeting these groups may be connected to immigration preferences. On the one hand, a central determinant of attitudes toward immigration is the perceived threat from immigration (Hainmueller \& Hopkins, 2014, 2015; Bansak, Hainmueller, \& Hangartner, 2016; Canetti-Nisim, Ariely, \& Halperin, 2008), and there are even fringe conspiracy theories concerning a "Muslim invasion" of Europe (Fekete, 2012). People who react negatively toward immigration may be more supportive of measures that target Muslims and also view the difference between Muslims and Islamic fundamentalists as smaller than other groups (see also findings in Sniderman et al., 2014; Petersen et al., 2011). On the other hand, research has shown that people are less supportive of measures that target themselves than other measures (Viscusi \& Zeckhauser, 2003; Best, Krueger, \& Pearson-Merkowitz, 2011; Sun, Wu, \& Poteyeva, 2011). It may be that those who view immigration in a 
negative light will be less supportive of targeting right-wing extremist terrorists, as doing so could infringe on their own rights. ${ }^{4}$ This leads to the third hypothesis:

Hypothesis 3 The support for security measures targeting different groups vary with attitudes toward immigration (a); specifically, the difference between Muslims and Islamists may be smaller for people who feel negatively about immigration (b).

While the mechanisms described above may be general mechanisms, they rely on evaluations that may vary between national contexts. This study uses data from four countries: Finland, France, Norway, and the US, and there is reason to believe that differences between these countries may lead to different levels of support for security measures and that country characteristics may moderate the effects of the terrorist threat. While France and the US have suffered recent large-scale attacks by Islamic fundamentalist terrorists, the only terrorist attack in Norway was carried out by a right-wing extremist. Malkki, Fridlund, and Sallamaa (2018) show that Finland has experienced attacks that could have been construed as terrorism, such as multiple school shootings and the bombing at the Myyarmanni shopping center. However, these events were not defined as terrorism in the Finnish debate. ${ }^{5}$ These differences in the type of terrorism experienced could cause differences in the baseline support for targeting different groups and even affect the responses to the experimental threats. Islamic terrorism is covered by the media to a high extent in all four countries, and the threat from Islamic terrorism is

\footnotetext{
${ }^{4}$ Piazza (2015) does find that people are both more supportive of targeting Muslims relative to rightwing extremists and that this difference is larger for people who do not believe that discrimination is a problem and that do not support equal rights. These questions were however asked after the experimental treatment something that could be problematic, see Montgomery, Nyhan, and Torres (2018).

5 The first Islamic attack in Finland, the knife attack in Turku in August 2017, transpired after the fielding of the survey used here.
} 
salient in the two countries that have not experienced Islamic terrorism. Thus, there is little reason to expect a quantitatively or qualitatively different effect regarding Islamic terrorism. Right-wing extremist attacks have primarily occurred in the US and Norway, so it is possible that this affects the baseline levels of support for targeting such rightwing extremists and that it moderates the effect of being reminded of the threat from these groups. The direction of these effects is unclear, however. On the one hand, one could expect prior experiences to increase the perceptions of danger from the threat, thus increasing the effect of being reminded of it in these countries. On the other, the threat may be more salient even when people are not reminded of it and the treatment effect may thus be lower. The last hypothesis suggests that there are differences by country:

Hypothesis 4 Support for security measures targeting different groups varies between countries (a) and prior experience with different types of terrorism moderates the effects of the terrorist news stories (b).

\section{Method and data}

This paper is based on data from a comparative survey originally fielded in five countries (Norway, Finland, France, the US and Spain) in January and February 2017 as part of the Disruptive Events Project. ${ }^{6}$ Because of differences in the survey experiment design, data from only four of the countries (Norway, Finland, France and the US) are used and the sample size is around 2000 respondents per country. Descriptive statistics are printed in Tables 4 to 5 in the appendix. ${ }^{7}$

\footnotetext{
${ }^{6}$ A comparative project including Norway, France, Finland, Spain and the US. It is funded through the Research Council of Norway's SAMRISK program.

${ }^{7}$ Figures 10 to 11 in the appendix plot balance tests between the experimental and control groups. The experimental groups are quite balanced on observable characteristics. The black squares plot the
} 
The analysis is based on a survey experiment where people were asked to read a newspaper story and then answer questions concerning counterterrorism measures. In the first part of the survey experiment, the respondents were asked to read one newspaper story. The story was chosen at random from a pool of four different stories (see the appendix for an example). Three of the stories described an impending terrorist attack where the perpetrators were either domestic Islamic extremists, recently immigrated Islamic extremists, or domestic right-wing extremists. The fourth story was a control story unrelated to terrorism. For the analyses, the two news stories about Islamic terrorism were combined into one. The news stories were designed to create an emotional reaction in the respondents and to resemble regular news articles.

In the second part of the experiment, the respondents were asked about their views on counterterrorism measures targeting a group. The respondents were asked about only one of four different groups, and this group varied orthogonally with the groups in the news story. The first three were "Islamists," "Muslims," and "right-wing extremists." The final control group was "people." The question was introduced with the text: "In thresholds proposed by Rubin (2001), i.e. that the absolute standardized difference in means should be below .25 and the variance ratio between 0.5 and 2.5. The figure design is borrowed from Legewie (2013).

${ }^{8}$ It is possible that some respondents do not recognize the difference between Islamists and Muslims. As will be clear in the analysis however, the results are different for the two groups, but this difference may be smaller than what would have been the case had a different term such as "Islamic fundamentalists" been used (as was used by Sniderman et al., 2014). In a study of Norwegian respondents by SteenJohnsen et al. (2016, ch. 4), the respondents did not differ in their views on Islamists relative to Muslims when asked about allowing the groups to use of a municipal building, but did do so when asked about members of the groups being hired as a teacher. Norwegian respondents thus exhibited an understanding of the groups being different, but this did not affect all measure of tolerance. However, by including a threatening scenario it will be possible to study how if this holds up under threat as Islamists should be more strongly connected to the threat than Muslims. 
the current situation, with many terrorist attacks in the past year, to what extent do you think the government should be allowed to:" and the following questions are those for respondents in the "Islamists"-group: ${ }^{9}$

- "hold Islamists in custody as long as they wish without putting them on trial?"

- "randomly stop and search Islamists on the street?"

- "surveil the e-mail accounts of Islamists?"

The respondents answered on a four-point scale ranging from "should absolutely not have the right to" to "should absolutely have the right to," and the three items were combined in an additive index with a Crohnbach's alpha of .84 and recoded to go from 0 to $1 .{ }^{10}$ The respondents were first exposed to either one of the three threatening news stories or the control story. Then they were asked about security measures targeting one specific group. The groups could be the same as in the news stories or they could be different. This way, it was possible to study the effect of being exposed to a news story about terrorism on supporting counterterrorism measures and whether it matters that the story was about the same or a different group than the one being targeted in the questions.

The choice of groups facilitates two important comparisons (see table 1 on page 14). On the one hand, it is possible to compare the effect of the terrorist threat on the answers concerning Islamists and Muslims. These two groups have similar religious beliefs, but are different in their political legitimacy and acceptance of democracy. On the other hand, Islamists can be compared to right-wing extremists - a group that has a different political motivation but is similar in its rejection of democracy. It is possible to compare

9 The word "Islamists" were changed to "Muslims", "right-wing extremists" and "people" for the other groups.

10 The Crohnbach's alpha varies between 0.71 and 0.90 in the different combinations of news stories, groups and countries. 
both how legitimacy of the group and how the majority/minority background of the groups affect tolerance and support for security measures.

A problem with this survey design is that the respondents may not have read the news story. To reduce the probability of including respondents that opted out of the treatment, the final analyses only include respondents that remained on the page of the news story for at least half of the median time spent on the page in the country. This excluded around 400 of the almost 7000 respondents and had the expected consequence of leading to stronger and less noisy treatment effects. ${ }^{11}$ However, even when including all respondents, the effects were consistent. The surveys were fielded at a time of high terrorist threat levels in the four countries, and the news stories could be considered comparable to what many respondents would experience regularly in newspapers and on television. Therefore, the effects present in this study may be considered on the lower end of the scale of what would happen after a terrorist attack. In addition, the questions on counter-terrorism did not follow directly after the news stories. The respondents first answered questions about their emotional reaction to the news stories (7), their trust level regarding different groups (10), and on civil liberties (1). This accounts for a total of 18 questions after the news stories. ${ }^{12}$ Since the effects of reading the news stories may diminish over time, the effects found here are on the lower end of what could be expected in a real-world setting. In addition, the introductory text to the questions reminds people of the present terrorist threat and could thus increase the perceived threat experienced by people in the control group who had not read a threatening news story.

\footnotetext{
11 About 100 respondents are removed per country ranging from 99 in Norway to 116 in Finland.

12 The civil liberties questions concerned the same groups as the questions on security measures. The respondents were thus asked about their support for the civil liberties of a Muslim, Islamist or right-wing extremist group or The Red Cross, before the questions on counter-terrorist measures.
} 
Table 1: Targets in the Experiment

\begin{tabular}{|c|c|l|}
\hline & Majority & Minority \\
\hline Democratic/Non-threatening & - & Muslims \\
\hline Undemocratic/Threatening & Right-wing extremists & Islamists \\
\hline
\end{tabular}

To measure attitudes toward immigration, respondents were asked about their views on immigration before the news stories. The questions were introduced with the sentence, "In the current situation, to what extent would you agree with the following statements:" and in the US the statements were: ${ }^{13}$

- "There are too many immigrants in the US"

- "Islam is a threat to the West"

- "American natives should have priority in employment compared to foreigners"

- "Immigration is a source of cultural enrichment"

- "Children born in the US to immigrant parents are as American as anyone else" The respondents answered on a four-point scale ranging from "disagree strongly" to "agree strongly". These five questions were used to create an additive index (with a Chronbachs alpha of 0.85 ) where respondents who answered on at least four of the questions were included. ${ }^{14}$ The index was recoded to go from 0 to 1 , with 1 denoting a very negative attitude toward immigration.

The following analysis begins with comparing the baseline differences in support for security measures. The terrorism threat experiment is then introduced and the possible consequences of a terrorist threat are examined. Finally, the effects of the moderating role of immigration attitudes is investigated and the effects are compared across the different

\footnotetext{
13 The text in italics varied with the country where the survey was fielded.

${ }^{14}$ Chronbach's alpha varies between 0.82 and 0.88 in the four countries.
} 
countries. Ordinary least square (OLS) regression is used to assure comparability across the different regression models (Mood, 2009), and marginal effects are used to increase the ease of interpretation (Leeper, 2018)..$^{15}$

\section{Results}

The results from the first five OLS models are printed in Table 2 on the next page. The first model is a baseline model that includes only the control variables and attitudes toward immigration. In this model, only the untreated respondents are included; that is, the people reading the control story and being asked about counterterrorism measures targeting "people". Model 2 includes respondents who read the threatening news stories and variables denoting which news story they read. Similarly, model 3 includes the different target groups of the second part of the experiment and the variables denoting the different groups that were asked about. Finally, models 4 and 5 include both parts of the experiment, and model 5 includes the interaction effects between the two groups and news stories.

Beginning with the first model, there are significant differences in the control group across the four countries, with the lowest support for security measures in the US and the highest in France. The correlation between immigration and support for security measures is .43 and statistically significant. In model 2, the news stories are included. Both of the news stories increase support for security measures and the other estimates stay more or less the same. In model 3, the news stories are removed and the background

\footnotetext{
${ }^{15}$ All analyses were run in R (R Core Team, 2018) and replication code is available on the author's website.
} 
Table 2: Support for security measures

\begin{tabular}{|c|c|c|c|c|c|}
\hline & & & Security in & & \\
\hline & Model 1 & Model 2 & Model 3 & Model 4 & Model 5 \\
\hline \multirow[t]{2}{*}{ Constant } & 0.138 & $0.300^{* *}$ & $0.344^{* *}$ & $0.332^{* *}$ & $0.326^{* *}$ \\
\hline & $(0.117)$ & $(0.056)$ & $(0.063)$ & $(0.031)$ & $(0.032)$ \\
\hline \multirow[t]{2}{*}{ Finland } & $0.190^{* *}$ & $0.168^{* *}$ & $0.095^{* *}$ & $0.103^{* *}$ & $0.103^{* *}$ \\
\hline & $(0.041)$ & $(0.019)$ & $(0.021)$ & $(0.010)$ & $(0.010)$ \\
\hline \multirow[t]{2}{*}{ France } & $0.246^{* *}$ & $0.197^{* *}$ & $0.108^{* *}$ & $0.093^{* *}$ & $0.093^{* *}$ \\
\hline & $(0.040)$ & $(0.019)$ & $(0.020)$ & $(0.010)$ & $(0.010)$ \\
\hline \multirow[t]{2}{*}{ Norway } & $0.118^{* *}$ & $0.130^{* *}$ & 0.020 & $0.030^{* *}$ & $0.030^{* *}$ \\
\hline & $(0.041)$ & $(0.018)$ & $(0.020)$ & $(0.010)$ & $(0.010)$ \\
\hline \multirow[t]{2}{*}{ Age } & 0.009 & 0.003 & $0.005^{*}$ & $0.005^{* *}$ & $0.005^{* *}$ \\
\hline & $(0.005)$ & $(0.002)$ & $(0.003)$ & $(0.001)$ & $(0.001)$ \\
\hline \multirow[t]{2}{*}{ Age Squared } & -0.0001 & -0.00001 & -0.0001 & $-0.00005^{* *}$ & $-0.00005^{* *}$ \\
\hline & $(0.0001)$ & $(0.00002)$ & $(0.00003)$ & $(0.00001)$ & $(0.00001)$ \\
\hline \multirow[t]{2}{*}{ Education } & -0.031 & 0.004 & -0.020 & $-0.022^{* *}$ & $-0.022^{* *}$ \\
\hline & $(0.031)$ & $(0.014)$ & $(0.015)$ & $(0.007)$ & $(0.007)$ \\
\hline \multirow[t]{2}{*}{ Female } & -0.041 & -0.024 & -0.026 & $-0.015^{*}$ & $-0.016^{*}$ \\
\hline & $(0.028)$ & $(0.013)$ & $(0.014)$ & $(0.007)$ & $(0.007)$ \\
\hline \multirow[t]{2}{*}{ Immigration } & & $0.462^{* *}$ & $0.452^{* *}$ & $0.500^{* *}$ & $0.500^{* *}$ \\
\hline & & $(0.025)$ & $(0.027)$ & $(0.013)$ & $(0.013)$ \\
\hline \multirow[t]{2}{*}{ Islamic Attack } & & $0.039^{*}$ & & $0.037^{* *}$ & $0.040^{*}$ \\
\hline & & $(0.016)$ & & $(0.008)$ & $(0.016)$ \\
\hline \multirow[t]{2}{*}{ R-W Attack } & & $0.045^{*}$ & & $0.027^{* *}$ & $0.047^{*}$ \\
\hline & & $(0.018)$ & & $(0.010)$ & $(0.019)$ \\
\hline \multirow[t]{2}{*}{ Muslims } & & & $-0.122^{* *}$ & $-0.129^{* *}$ & $-0.121^{* *}$ \\
\hline & & & $(0.019)$ & $(0.010)$ & $(0.019)$ \\
\hline \multirow[t]{2}{*}{ Islamists } & & & 0.015 & -0.005 & 0.016 \\
\hline & & & $(0.020)$ & $(0.010)$ & $(0.019)$ \\
\hline \multirow[t]{2}{*}{ R-W Extremists } & & & -0.012 & -0.010 & -0.012 \\
\hline & & & $(0.020)$ & $(0.010)$ & $(0.020)$ \\
\hline \multirow[t]{2}{*}{ Islamic Attack X Muslims } & & & & & -0.003 \\
\hline & & & & & $(0.023)$ \\
\hline \multirow[t]{2}{*}{ R-W Attack X Muslims } & & & & & -0.025 \\
\hline & & & & & $(0.027)$ \\
\hline \multirow[t]{2}{*}{ Islamic Attack X Islamists } & & & & & -0.016 \\
\hline & & & & & $(0.024)$ \\
\hline \multirow[t]{2}{*}{ R-W Attack X Islamists } & & & & & -0.051 \\
\hline & & & & & $(0.027)$ \\
\hline \multirow[t]{2}{*}{ Islamic Attack X R-W Extremists } & & & & & 0.007 \\
\hline & & & & & $(0.024)$ \\
\hline \multirow[t]{2}{*}{ R-W Attack X R-W Extremists } & & & & & -0.006 \\
\hline & & & & & $(0.027)$ \\
\hline $\mathrm{N}$ & 451 & 1689 & 1593 & 6535 & 6535 \\
\hline R-squared & 0.119 & 0.266 & 0.238 & 0.271 & 0.272 \\
\hline Adj. R-squared & 0.106 & 0.261 & 0.233 & 0.270 & 0.270 \\
\hline
\end{tabular}


Figure 1: Marginal effects of the news stories for different groups

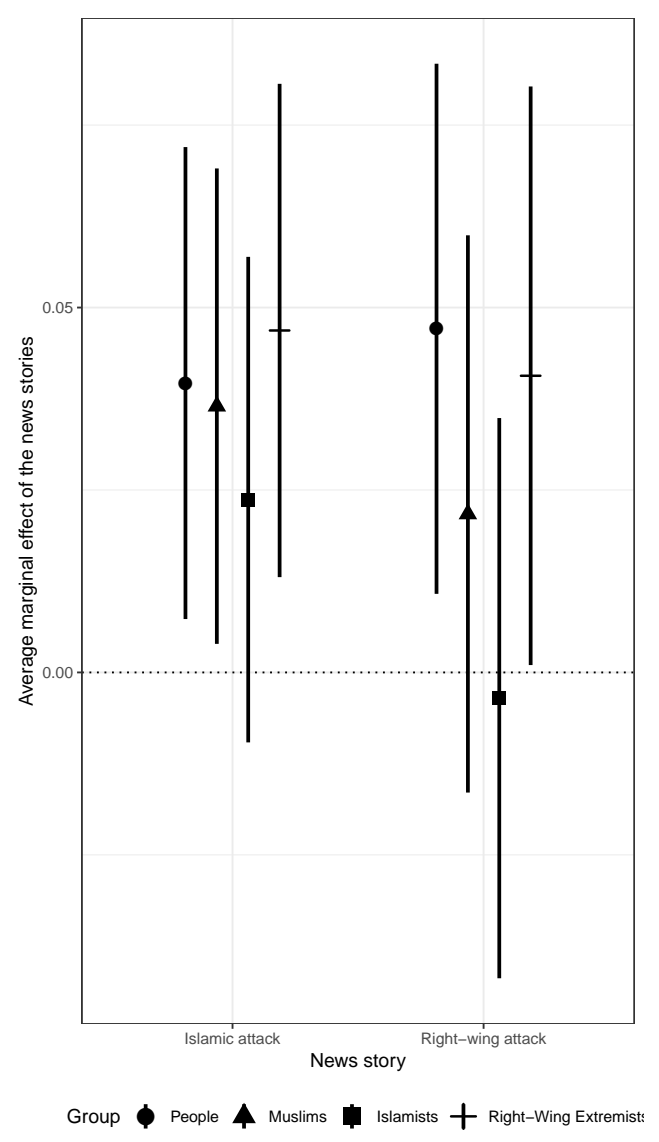

Figure 2: Marginal effects of the groups for news stories

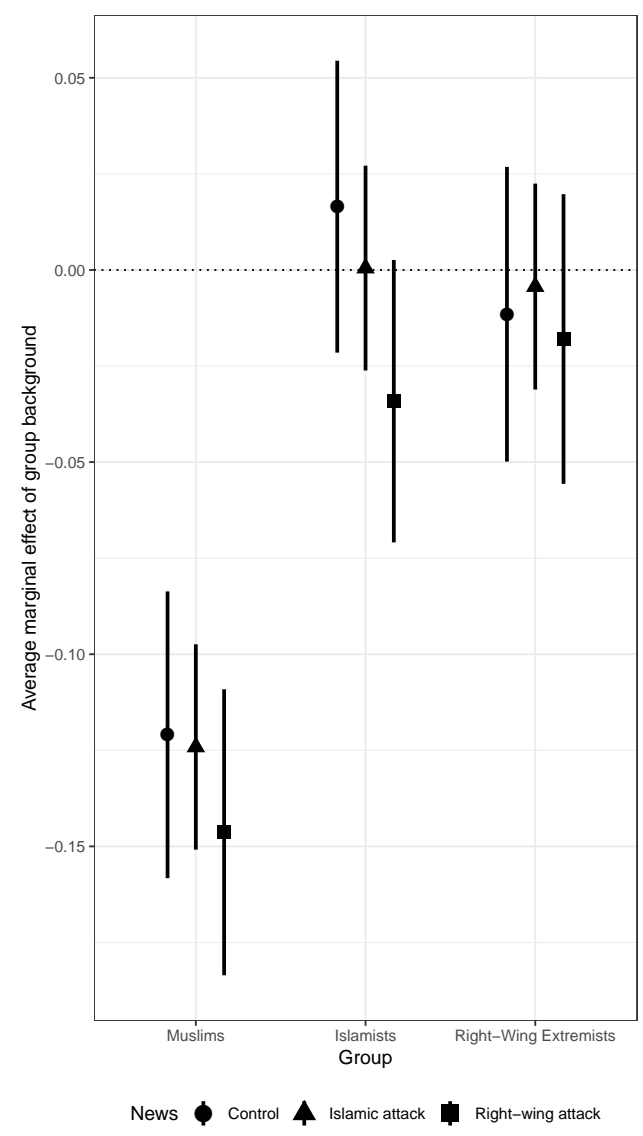

of the target group is included. The support for security measures seems to vary primarily between Muslims and the other groups, and people are less willing to target Muslims. For the two other groups, the support is similar to the "people"-group. The estimated effects of the news stories are smaller when both the news stories and the target groups are included.

Finally, the last model includes interaction estimates for the two experiments. To interpret this model, the marginal effects of the interactions are plotted in figures 1 to 2 on this page. These figures show the effect of being exposed to the news stories about different sub-groups (figure 1) and the effects of the different groups for respondents exposed to the different news stories (figure 2). Beginning with figure 1, the effects of the 
news stories seem to depend on the target of the security measures being the same group as the news story. Support for targeting Muslims is only affected by the Islamic attack story, while the effect on Islamists is in the same direction but not significant. The right-wing attack news story does not change the support for targeting either Muslims or Islamists. For the people group and the right-wing extremist group, there are effects observed from both news stories, and people become more positive about targeting both groups when they have read the terrorist news stories relative to when they read the control story. The marginal effects of the groups are plotted in figure 2. Here, the pattern is more stable, with relatively similar marginal effects of the group across news stories. However, for both Muslims and Islamists, there seems to be a slightly negative respondent pattern for those who read the right-wing terrorism news story. The respondents reading this story support the targeting of Islamists to a lower extent than targeting people (statistically significant at .1). However, this may be caused by both a negative effect on support for targeting these groups and a larger positive effect of targeting "people".

Returning to the hypotheses, the results so far seem to support hypotheses 1a and 2a. There is higher support for security measures in general by people who have read the news stories (H1a), and there is a difference in support for targeting Muslims relative to the other three groups (H2a). Hypothesis $1 \mathrm{~b}$ is difficult to evaluate. On the one hand, the right-wing terrorist news did not increase support for targeting Muslims and Islamists. On the other, the Islamic terrorism news story did increase support for targeting rightwing extremists and people. Hypothesis $2 \mathrm{~b}$ seems to receive some support. There is stronger evidence of an effect from the Islamic terrorist news story on support for targeting Muslims rather than Islamists. The estimates on support for targeting Islamists are not significant, and the differences in size between the estimates are also small and not 
significant.

\subsection{Immigration attitudes}

To measure how immigration attitudes may moderate the relationship between threat, target groups, and policy support, interactions between immigration attitudes and the survey experiment are included in the three models in table 3 in the appendix. The predicted support for security measures is plotted in figure 3 on the next page. This figure shows how support (of the group reading the control news story) for security measures is dependent on target group affiliation and prior attitudes toward immigration. Beginning with immigration attitudes, the predicted support for security measures targeting the first three groups seems to be dependent on attitudes toward immigration, and the more negative a person is, the more the person supports security measures. For the last group — right-wing extremists — this is not the case. This relationship is slightly curve-linear, but support seems to be quite stable across attitudes toward immigration.

The marginal effects of the news stories for the different groups and for different attitudes toward immigration are plotted in Figure 4 on page 21. In the plots, the news stories are compared to the control story and only the difference from the control story is plotted. ${ }^{16}$ Beginning with people and Muslims, there is a positive effect with the Islamic news story. This effect is curve-linear and only affects the people who show medium support for immigration. The estimated effect of the right-wing extremist news story is positive for targeting Muslims by people who are relatively negative toward immigration,

\footnotetext{
16 The dotted line may be interpreted as the effect of the control story.
} 
Figure 3: Predicted support for security measures targeting different groups by attitudes toward immigration

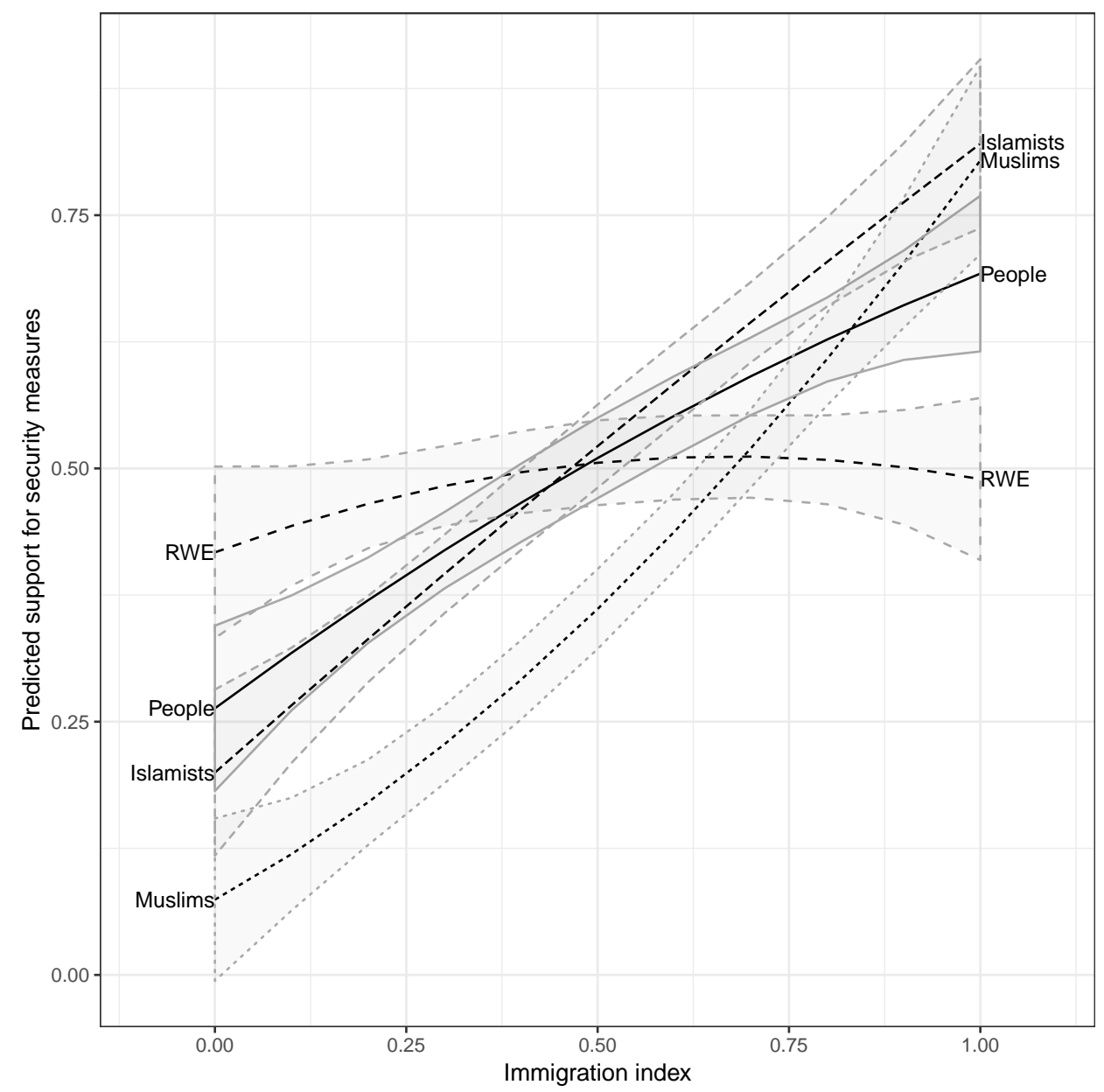

but it is only significant at the .1 level for a few attitude types toward immigration. In addition, this group seems to increase their support for targeting "people". Moving to Islamists, there are no statistically significant effects with either of the news stories. Both of the news stories increase support for targeting right-wing extremists in the bottom right plot. However, while the Islamic news story primarily affects the respondents who are the most negative toward immigration, there is a curve-linear relationship between immigration attitudes and the effect of the right-wing extremist news story. While it increases support for security measures among those whose attitudes toward immigration are in the middle, the respondents at the extreme ends of the scale are not affected by 
Figure 4: Marginal effects of the news story on support for targeting different groups by attitudes toward immigration

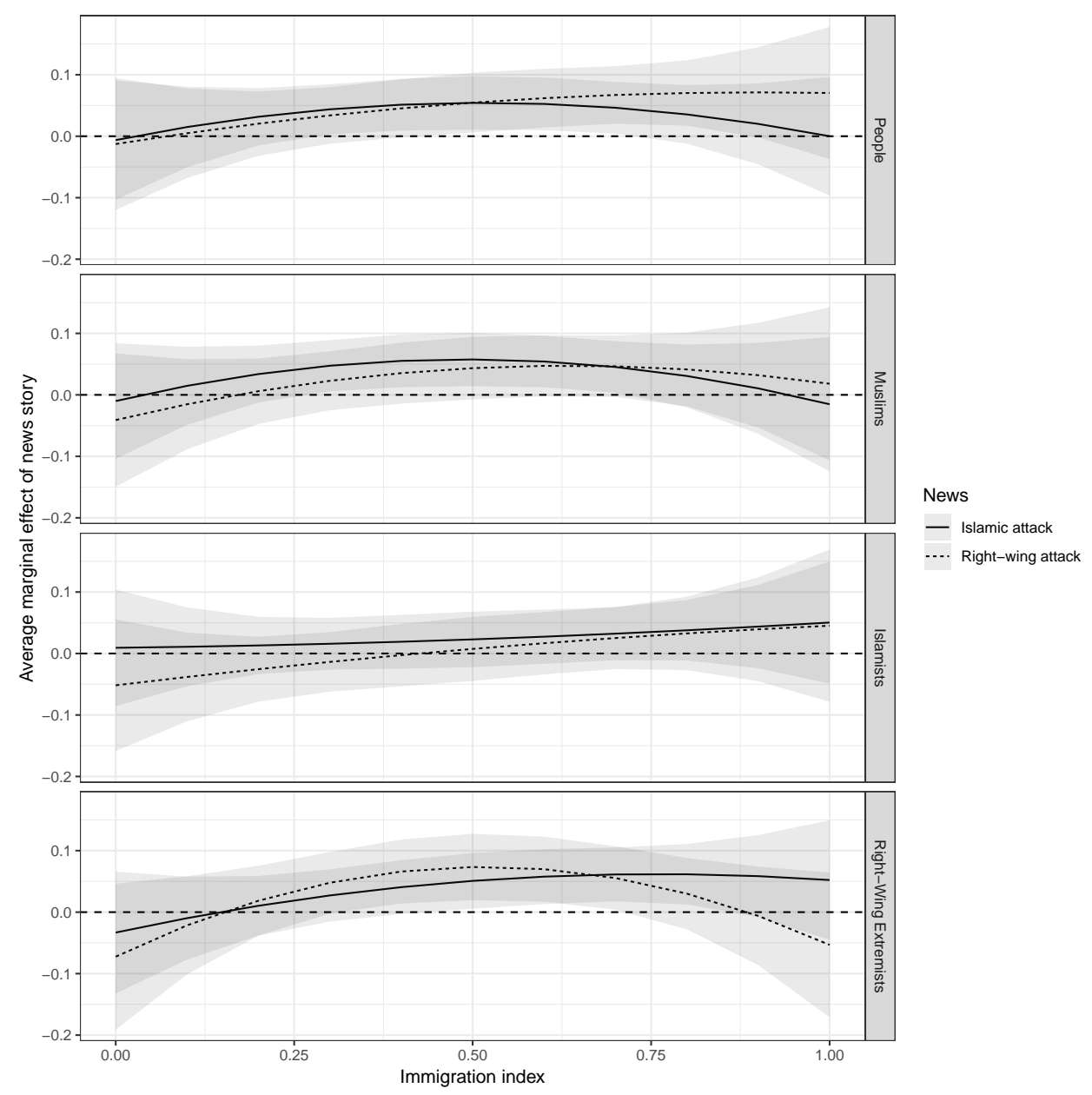

the news story.

The group effects in figure 5 on the next page, show a similar pattern. Here, the marginal effects of being asked about a group are plotted, and the control group comprises those asked about "people". Relative to the "people" group, the respondents are less willing to target Muslims for all news story treatments, and this is evident from the line for Muslims being below the dotted line. However, support for targeting Muslims increases the more negative one is toward immigration; for the people most negative toward immigration, there is higher support for targeting Muslims rather than "people". The pattern for Islamists is similar to the one for Muslims, but there is more support for 
Figure 5: Marginal effects of the targeted group by news stories and attitudes toward immigration

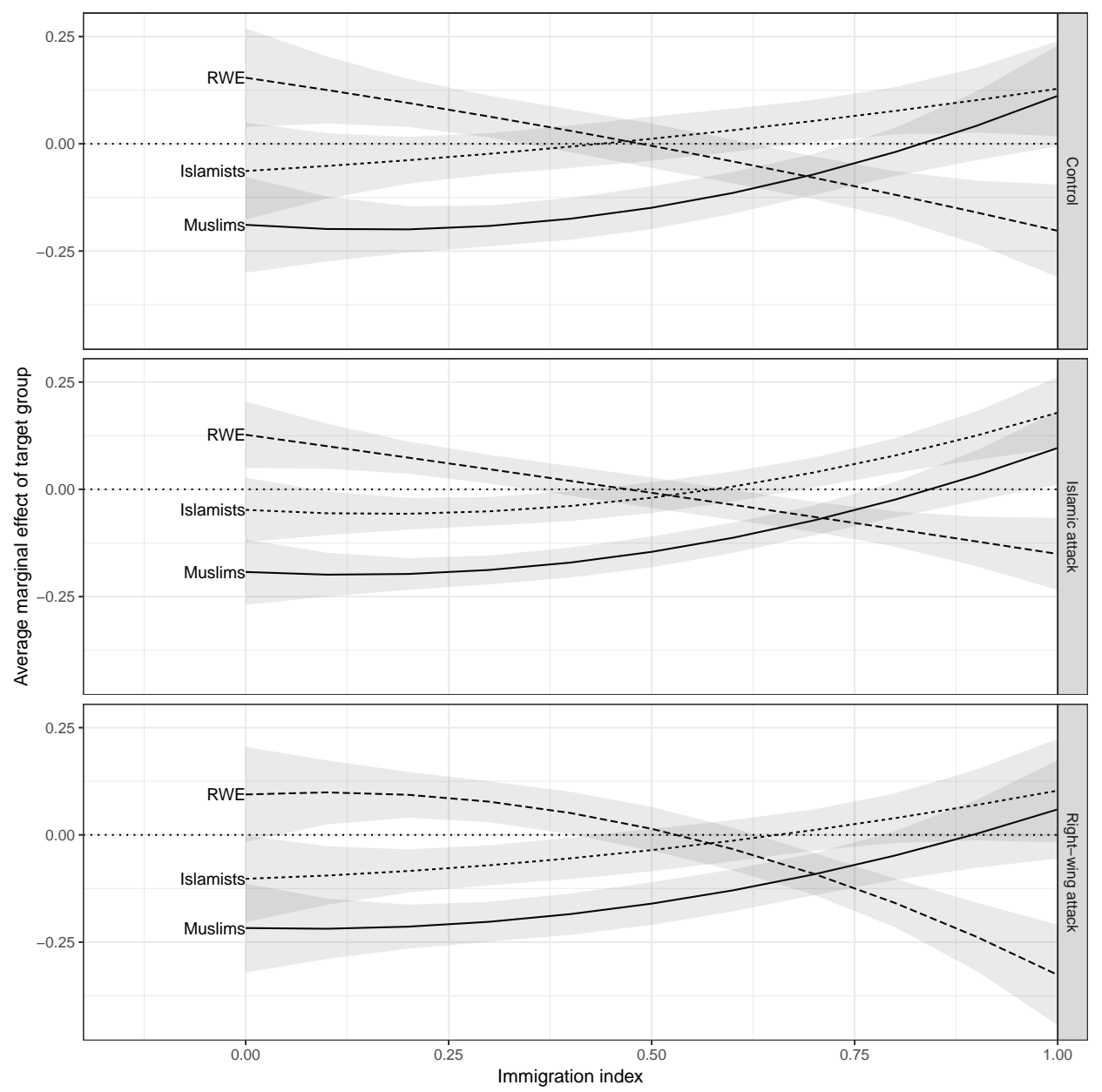

targeting Islamists across all levels of immigration attitudes except for the respondents who are the most negative toward immigration. The pattern is the exact opposite for right-wing extremist ("RWE" in the plot). The respondents who feel negatively about immigration feel negatively about targeting right-wing extremists relative to people, while those more positive to immigration are conversely positive toward targeting right-wing extremists.

The effect of the target group does not seem to vary much between the news stories. There is a slightly more negative attitude toward targeting Islamists relative to "people" by the respondents reading the right-wing terrorism story. In addition, the combination of 
Figure 6: Marginal effects of the news story by targeted group in the different countries

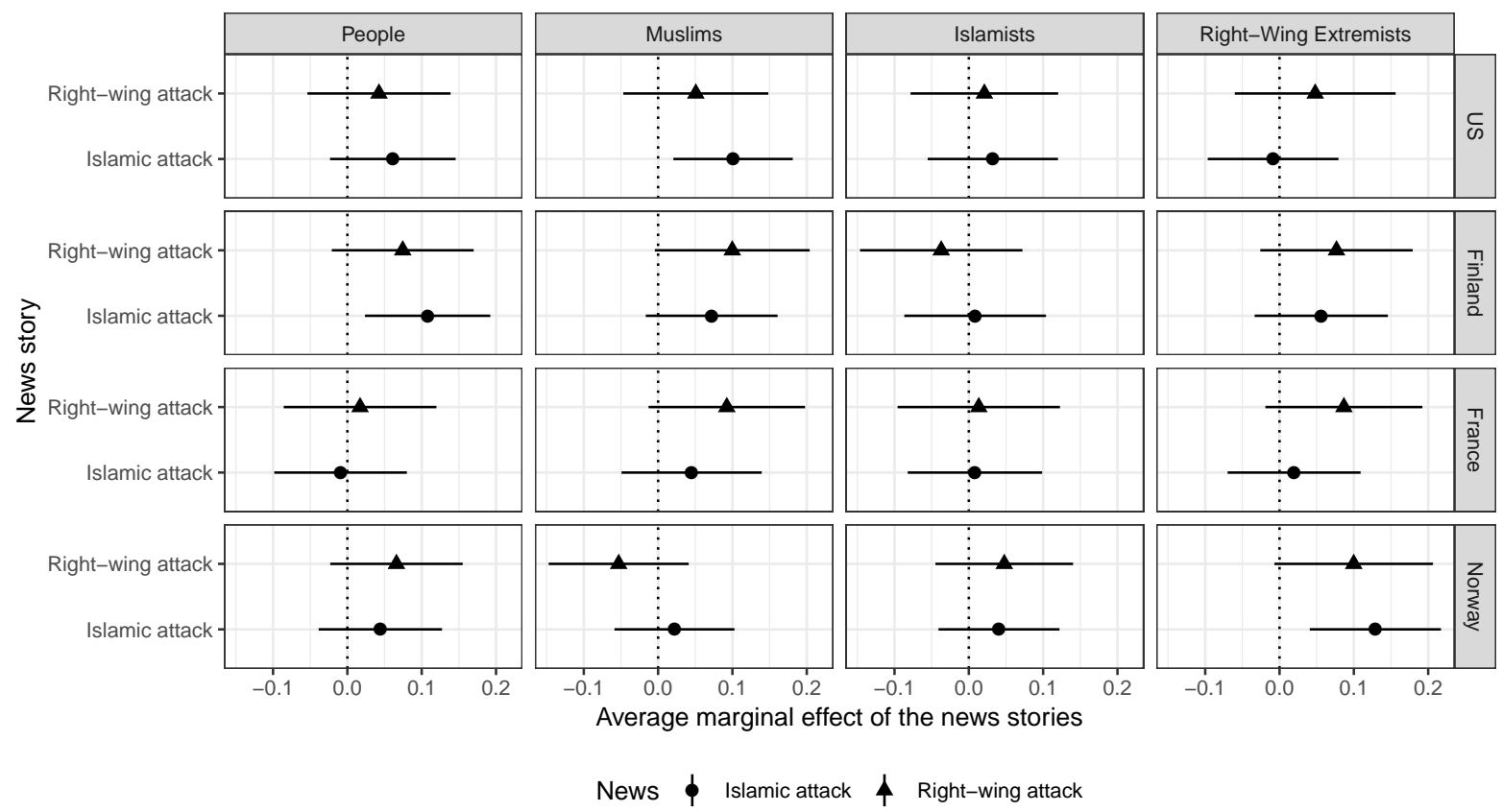

a right-wing extremist news story and being asked about targeting right-wing extremists make those most negative toward immigration even more negative regarding targeting right-wing extremists relative to people. This is not the case for people with more positive attitudes toward immigration: if the news story has any effect, it is positive. The effect of the news story treatment is thus the opposite of the expected pattern for the people who are the most negative toward immigration.

Going back to the third hypothesis, there is some support for both of its parts. There is higher support for security measures among people with negative attitudes toward immigration (H3a) when they are asked about Muslims, Islamists and "people". However, this is not the case when targeting right-wing extremists. The relationship between immigration attitudes and support for security measures is thus dependent on the group being targeted by the measures. The last part of the hypothesis (H3b) is also supported. Those most negative toward immigration do not distinguish between Muslims and Is- 
lamists. Rather, those most negative toward immigration support targeting both groups to the same extent.

\subsection{Country differences}

To test if there are important country differences, the full model was run with an interaction across country, immigration, and the two experimental treatments. The predicted support is plotted in figure 9 in the appendix. This support shows a similar pattern as that in the pooled model for the four countries. However, in the US, the support for targeting right-wing extremists seems to follow the same positive correlation with attitudes toward immigration as the three other groups. This is not the case in the three other countries and these are more similar to the results in the pooled model.

Moving to the marginal effects in figures 6 to 7 on pages 23-40, there are some differences between the countries. Two countries seem to stand out regarding the effects of the news stories. First, in France, there seem to be smaller effects than those observed in other countries, and it is the right-wing extremist news story that has the largest estimates (in regards to support for targeting right-wing extremists and Muslims). This may indicate that the Islamic terrorist threat was so present in the French respondents' thoughts that the experiment did not change their attitudes. Before January 2017, France had suffered a wave of Islamic terrorism, with the most recent large-scale attack being the one in Nice in July the year before. The right-wing extremist terrorist story may have presented the respondents with new information that affected their support (only significant at .1).

The Norwegian estimates also deviate from the general findings and effects in the three other countries. The effect of the right-wing extremist news story on support for 
targeting Muslims is negative (albeit not significant), whereas it is positive in the other countries. For the other countries, there are positive estimates for this effect (significant at .1 in France and Finland) and removing Norway from the pooled analyses reveals a significant (.05) and positive effect of the right-wing extremist news story on support for targeting Muslims at about the same size as the effect of the Islamic news story (not printed). The Norwegian reaction to the right-wing extremist news story can be better understood in light of the Norwegian experience with the right-wing extremist attacks in 2011 and the mobilization that came in the aftermath. Indeed, multiple studies show a positive effect from the attacks on attitudes toward minorities (Jakobsson \& Blom, 2014; Solheim, 2018; Wollebæk, Steen-Johnsen, Enjolras, \& Ødegård, 2013). It is thus possible that being reminded of this terror threat led Norwegians to mobilize in a tolerant direction.

Figure 7 plots the effects of the groups' backgrounds for the different news treatments in the different countries. The general pattern is again not present in France, where support for targeting right-wing extremists is at the same level as support for targeting Muslims and is well below the support for targeting both Islamists and "people". The difference in support for targeting Muslims relative to "people" varies, with no difference in the US, and larger differences in Finland and France. The largest difference is observed in Norway. However, the difference in support for targeting Islamists relative to Muslims seems stable between the countries.

\section{Discussion}

This paper started out with a discussion on the possible consequences of terrorism in the West, where a domestic Muslim minority is combined with a threat from Islamic terrorism 
and a highly salient debate on immigration. The introduction questioned whether this situation would facilitate overreactions toward terrorism because it may be easier to target minorities such as Muslims than it is to target members of the majority. Indeed, it has been found that people are more supportive of measures targeting others (Viscusi \& Zeckhauser, 2003) and that Western countries with larger Muslim minorities have enacted laws that directly target immigrants to a higher extent than other countries (Epifanio, 2016). The literature on civil liberties and counterterrorism measures, however, is divided on the consequences of such threats. On the one hand, there is an optimistic view of seeing support for civil liberties as a bulwark against overreactions, arguing that people can distinguish between threatening and non-threatening groups and that a threat only increases support for measures targeting the causes of the threat. On the other, there is a more pessimistic view that a threat reduces support for civil liberties in general and that the threat from terrorism and from immigration may reduce people's ability to differentiate between groups. As one could expect, the results do not support just one of these views, but there are reasons for both optimism and pessimism depending on interpretation and what results one is interested in.

The first finding is in clear support for the differentiation between different groups (H2a). The respondents do not support counterterrorism measures against all groups to the same extent, and this seems to follow the expected pattern where there is more support for targeting Islamists and right-wing extremists and less support for targeting Muslims (see also Christensen \& Aars, 2017). Muslims are thus not conflated with Islamists and do not seem to be perceived as a threatening group. Interestingly, targeting the control group of "people", was supported to a higher extent than targeting Muslims. This support was closer in degree to the two threatening groups (except for in the US). This is 
puzzling, as one could have expected that the respondents would interpret "people" as a category that they themselves were members of and would be more negative toward only the threatening groups. One possible explanation is that the respondents interpreted the "people" category as one that included the threatening groups, but not people like themselves. The correlation between support for targeting "people" and attitudes toward immigration is interesting because it follows the same pattern as support for targeting Muslims and Islamists. There is a positive correlation between immigration attitudes and support for targeting Muslims, Islamists, and people, but this is not the case for rightwing extremists. Since this pattern is not present in the support for targeting right-wing extremists, it is possible that the respondents have interpreted the "people" group in this context as a group connected to Muslims.

A second possibility is that the respondents are particularly negative toward measures that target Muslims. The measures asked about were: hold in custody indefinitely, random searches on the street, and surveillance of e-mail accounts. These may have been seen as illegitimate when targeting Muslims, but not when the target is more broadly or more narrowly defined. The respondents may thus paradoxically see the broader measure as less invasive because the targets comprise the total population rather than a smaller legitimate subgroup. The results here indicate that people are more sensitive toward measures that target specific subgroups when the groups are not threatening or transgressive than toward measures that target the whole population. The idea that support for civil liberties may serve as a bulwark against ineffective overreactions thus receives some support here (Abrahms, 2007). This is crucial because repressing minority rights - especially religious expressions - causes grievances that in turn have been found to lead to terrorism (Piazza, 2017). For terrorist groups, the creation of such 
overreactions is indeed a goal, as it may increase terrorist group support relative to the state (Wilkinson, 2006).

At the beginning of the analysis, the effects of a threat did not fully conform with neither the expectations based on Marcus et al. (1995) (H1a) nor Albertson and Gadarian (2015) (H1b). On the one hand, targeting right-wing extremists received more support from respondents who had read about both right-wing extremist and Islamic terrorism. On the other, there was also an increase in support for targeting Muslims, but this only happened for the people who had read the Islamic terrorism news story. When the analyses were run with an interaction across countries, however, there emerged an interesting pattern. There was a positive effect from the right-wing extremist news story on support for targeting Muslims in the US, France, and Finland, but not in Norway. This effect in the pooled sample without Norway was even the same size as the effect of the Islamic news story. The effects found here thus seem to follow the expectations from Marcus et al. (1995), in that anxiety reduces support for civil liberties in general. This then leads to increased support for counterterrorism measures in general and not only toward the specific group causing the threat (H1a).

In the Norwegian case, it is possible that the experience of the right-wing extremist terrorist attacks in 2011 led to a different reaction toward the right-wing extremist news story. After the attacks, it is important to note that the framing by the political leadership and in public demonstrations emphasized tolerance as a response to the attacks. Research has also found that the public both increased its out-group trust and support for a liberal immigration policy (Solheim, 2018; Jakobsson \& Blom, 2014; Wollebæk et al., 2013). It is possible that this may have created a different reaction to the news story than in the other countries (H4) and why Norwegians thus did not increase their support for targeting 
Muslims after reading about right-wing extremist terrorism. Similarly, the minor effects found in France regarding the news stories may indicate that the terrorist threat was already highly salient in that country. French respondents thus did not change their attitudes to the same extent as the other respondents after reading the stories. These possible consequence of past experiences with terrorism could be interesting to research in further comparative studies.

The results show that, rather than reacting only to the undemocratic and threatening groups, people increase their support for targeting the democratic groups as well. This goes against the optimistic findings from Denmark (Sniderman et al., 2014). This may be caused by important differences between the terrorist threat and the Danish debate on caricatures. There are more consistent effects on the support for targeting Muslims and for targeting Islamists. This could indicate that the baseline support for targeting Islamists is higher because it considers the transgressive characteristics of the group (Sniderman et al., 2014), or perhaps because thinking about Islamists makes people anxious (Marcus et al., 1995). Reminding people of the threat from this group may not change their perceptions of Islamists as much as it does for targeting Muslims, and democratic groups may seem more transgressive when reminded of terrorism. While (Piazza, 2015) found similar levels of support for targeting the two groups, the reduction in difference regarding support for targeting Muslims relative to Islamists is not statistically significant in the analyses here. However, the treatments in these two studies could be seen as the two extremes of a scale and should be further explored through studies using treatments that are stronger than those used here, but while not defining the Muslim group as terrorists, which was done by Piazza (2015).

The inclusion of immigration attitudes in the analyses also shows that there are re- 
spondents who do not perceive a difference between Muslims and Islamists (H3). While the majority supports targeting Islamists to a higher extent than targeting Muslims, this is not the case for those who are the most negative toward immigration. This group do not seem to distinguish between Muslims and Islamists and supports the targeting of both groups to a very high extent. The attitudes toward targeting Islamists and Muslims seem to be intrinsically connected to attitudes toward immigration and moving from one end of the scale to the other on immigration means moving three quarters of the scale on support for security. The public seems very divided on this matter, and none of the experimental treatments have a similarly sized effect.

This paper has shown that there are clear baseline differences in support for targeting Muslims relative to Islamists and right-wing extremists. This is an important distinction to make and shows that the public does not conflate Islamists with Muslims in general. However, this distinction is reduced when people are reminded of terrorism and is not even made by people who are very negative toward immigration. Therefore, it is possible that stronger reminders of terrorism, such as real world attacks, would reduce it further and that continued debates over immigration may lead more people to see the two groups as the same. There are also some indications of a correlation between immigration attitudes and support for targeting "people". Coupled with the finding of increased support for targeting "people" when under a terrorist threat, this may indicate that respondents perceived the "people" category as being associated with Islamists or Muslims. It is also possible that an increase in support for counterterrorism policies in general is larger because the respondents do not consider themselves as part of the group being targeted. This could mean that the current wave of Islamic terrorism might lead to higher support for illiberal counterterrorism measures than for other types of terrorism that are less 
connected to out-groups. 


\section{References}

Abrahms, M. (2007, April). Why Democracies Make Superior Counterterrorists. Security Studies, 16(2), 223-253.

Albertson, B. \& Gadarian, S. K. (2015). Anxious Politics: Democratic Citizenship in a Threatening World. New York, NY, US: Cambridge University Press.

Bansak, K., Hainmueller, J., \& Hangartner, D. (2016, October 14). How Economic, Humanitarian, and Religious Concerns Shape European Attitudes Toward Asylum Seekers. Science, 354(6309), 217-222.

Best, S. J., Krueger, B. S., \& Pearson-Merkowitz, S. (2011). Al Qaeda Versus Big Brother: Anxiety About Government Monitoring and Support for Domestic Counterterrorism Policies. Political Behavior, 34(4), 607-625.

Bozzoli, C. \& Müller, C. (2011, December). Perceptions and attitudes following a terrorist shock: Evidence from the UK. European Journal of Political Economy, 27, 89-106.

Canetti-Nisim, D., Ariely, G., \& Halperin, E. (2008). Life, Pocketbook, or Culture: The Role of Perceived Security Threats in Promoting Exclusionist Political Attitudes toward Minorities in Israel. Political Research Quarterly, 61(1), 90-103.

Christensen, D. A. \& Aars, J. (2017, May 10). Nordmenns holdninger til telefonavlytting: Resultater fra et surveyeksperiment. Tidsskrift for samfunnsforskning, 58(2), 191209.

Das, E., Bushman, B. J., Bezemer, M. D., Kerkhof, P., \& Vermeulen, I. E. (2009, May). How terrorism news reports increase prejudice against outgroups: A terror management account. Journal of Experimental Social Psychology, 45(3), 453-459. 
Davis, D. W. \& Silver, B. D. (2004). Civil Liberties vs. Security: Public Opinion in the Context of the Terrorist Attacks on America. American Journal of Political Science, $48(1), 28-46$.

Echebarria-Echabe, A. \& Fernández-Guede, E. (2006). Effects of Terrorism on Attitudes and Ideological Orientation. European Journal of Social Psychology, 36(2), 259265.

Epifanio, M. (2016, August 7). The Politics of Targeted and Untargeted Counterterrorist Regulations. Terrorism and Political Violence, 28(4), 713-734.

Fekete, L. (2012). The Muslim conspiracy theory and the Oslo massacre. Race \& Class, 53(3), 30-47.

Finseraas, H. \& Listhaug, O. (2013). It Can Happen Here: The Impact of the Mumbai Terror Attacks on Public Opinion in Western Europe. Public Choice, 156(1-2), 213228.

Haider-Markel, D. P., Joslyn, M. R., \& Al-Baghal, M. T. (2006, December). Can We Frame the Terrorist Threat? Issue Frames, the Perception of Threat, and Opinions on Counterterrorism Policies. Terrorism and Political Violence, 18(4), 545-559.

Hainmueller, J. \& Hopkins, D. J. (2014, May 11). Public Attitudes Toward Immigration. Annual Review of Political Science, 17(1), 225-249.

Hainmueller, J. \& Hopkins, D. J. (2015, July). The Hidden American Immigration Consensus: A Conjoint Analysis of Attitudes toward Immigrants. American Journal of Political Science, 59(3), 529-548.

Huddy, L., Feldman, S., Taber, C. S., \& Lahav, G. (2005). Threat, Anxiety, and Support of Antiterrorism Policies. American Journal of Political Science, 49(3), 593-608. 
Huddy, L., Feldman, S., \& Weber, C. (2007). The Political Consequences of Perceived Threat and Felt Insecurity. Annals of the American Academy of Political and Social Science, 614(1), 131-153.

Jakobsson, N. \& Blom, S. (2014). Did the 2011 Terror Attacks in Norway Change Citizens' Attitudes Toward Immigrants? International Journal of Public Opinion Research, $26(4), 475-486$.

Lahav, G. \& Courtemanche, M. (2012, September). The Ideological Effects of Framing Threat on Immigration and Civil Liberties. Political Behavior, 34(3), 477-505.

Leeper, T. J. (2018, May 22). Interpreting Regression Results using Average Marginal Effects with $R$ 's margins.

Legewie, J. (2013). Terrorist Events and Attitudes toward Immigrants: A Natural Experiment. American Journal of Sociology, 118(5), 1199-1245.

Malhotra, N. \& Popp, E. (2012). Bridging Partisan Divisions over Antiterrorism Policies: The Role of Threat Perceptions. Political Research Quarterly, 65(1), 34.

Malkki, L., Fridlund, M., \& Sallamaa, D. (2018, September 3). Terrorism and Political Violence in the Nordic Countries. Terrorism and Political Violence, 30 (5), 761-771. Marcus, G. E., Neuman, W. R., \& MacKuen, M. (2000). Affective intelligence and political judgment. Chicago, IL, US: University of Chicago Press.

Marcus, G. E., Sullivan, J. L., Theiss-Morse, E., \& Wood, S. L. (1995). With Malice Toward Some: How People Make Civil Liberties Judgments. New York, NY, US: Cambridge University Press.

Merolla, J. L. \& Zechmeister, E. J. (2009). Democracy at Risk. How Terrorist Threats Affect the Public. Chicago Studies in American Politics. Chicago, IL, US: The University of Chicago Press. 
Mondak, J. J. \& Hurwitz, J. (2012). Examining the Terror Exception: Terrorism and Commitments to Civil Liberties. Public Opinion Quarterly, 76(2), 193-213.

Montgomery, J. M., Nyhan, B., \& Torres, M. (2018, March 30). How Conditioning on Posttreatment Variables Can Ruin Your Experiment and What to Do about It. American Journal of Political Science, Advance online publication, 1-16.

Mood, C. (2009). Logistic Regression: Why We Cannot Do What We Think We Can Do, and What We Can Do About It. European Sociological Review, 26(1), 67-82.

Petersen, M. B., Slothuus, R., Stubager, R., \& Togeby, L. (2011, July). Freedom for All? The Strength and Limits of Political Tolerance. British Journal of Political Science, $41(03), 581-597$.

Piazza, J. A. (2015, December). Terrorist Suspect Religious Identity and Public Support for Harsh Interrogation and Detention Practices: Terror Suspect Identity and Interrogation and Detention. Political Psychology, 36(6), 667-690.

Piazza, J. A. (2017, January 2). Repression and Terrorism: A Cross-National Empirical Analysis of Types of Repression and Domestic Terrorism. Terrorism and Political Violence, 29(1), 102-118.

Piazza, J. A. \& Walsh, J. I. (2010, July). Physical Integrity Rights and Terrorism. PS: Political Science Ef Politics, 43(03), 411-414.

R Core Team. (2018). R: A Language and Environment for Statistical Computing. Vienna, Austria.

Rubin, D. B. (2001). Using propensity scores to help design observational studies: Application to the tobacco litigation. Health Services and Outcomes Research Methodology, 2(3), 169-188. 
Schuurman, B. (2013, February). Defeated by Popular Demand: Public Support and Counterterrorism in Three Western Democracies, 1963-1998. Studies in Conflict \& Terrorism, 36(2), 152-175.

Sniderman, P. M., Petersen, M. B., Slothuus, R., \& Stubager, R. (2014). Paradoxes of liberal democracy : Islam, Western Europe, and the Danish cartoon crisis. Princeton, NJ, US: Princeton University Press.

Solheim, Ø. B. (2017). Are we all Charlie? The international and domestic effects of terrorist attacks. Paper presented at the ECPR General Conference at the University of Oslo, Norway, 6-9 September 2017.

Solheim, Ø. B. (2018, June 4). Right-Wing Terrorism and Out-Group Trust: The Anatomy of a Terrorist Backlash. Terrorism and Political Violence, Advance online publication, 1-19.

Steen-Johnsen, K., Fladmoe, A., \& Midtbøen, A. H. (2016). Ytringsfrihetens grenser: Sosiale normer og politisk toleranse. Institutt for samfunnsforskning. Oslo, Norway.

Stouffer, S. A. (1955). Communism, Conformity, and Civil Liberties: A Cross-Section of the Nation Speaks Its Mind. Garden City, NY, US: The Country Life Press.

Sun, I. Y., Wu, Y., \& Poteyeva, M. (2011, July). Arab Americans' Opinion on Counterterrorism Measures: The Impact of Race, Ethnicity, and Religion. Studies in Conflict 83 Terrorism, $34(7), 540-555$.

Viscusi, W. K. \& Zeckhauser, R. J. (2003, March). Sacrificing civil liberties to reduce terrorism risks. Journal of Risk and Uncertainty, 26(2-3), 99-120.

Walsh, J. I. \& Piazza, J. A. (2010). Why Respecting Physical Integrity Rights Reduces Terrorism. Comparative Political Studies, 43(5), 551-577. 
Wilkinson, P. (2006). Terrorism Versus Democracy: The Liberal State Response (). Cass Series: Political Violence. New York, NY, US: Routledge.

Wollebæk, D., Steen-Johnsen, K., Enjolras, B., \& Ødegård, G. (2013). Rallying Without Fear. In D. Antonius \& S. J. Sinclair (Eds.), The Political Psychology of Terrorism Fears (pp. 246-262). Oxford, UK: Oxford University Press. 


\section{Appendix: Newspaper story example}

We're interested in how people understand what they read in the news. Please read this recent article from a national newspaper and we'll ask you some questions about it afterwards

\section{The Ministry of Justice called for a press conference:}

\section{Fear of terror attacks in Norway}

The Ministry of Justice urges local law enforcement to increase surveillance after the discovery of suspicious documents in an Oslo apartment.

The documents purportedly plan a large-scale Paris-style terrorist attack against a variety of public targets, including government building, schools, and athletic stadiums in Norway, said a spokesperson of the Ministry of Justice when they today, on short notice called a press conference.

\section{Connections to Islamic extremist groups}

The apartment where the documents were found was rented to two young men who recently arrived in Norway from Iraq. According to sources we have spoken to, the two men are supposed to have ties with the Islamic State terrorist group. Documents found on their laptops are said to contain concrete plans for a major terrorist attack in Oslo in the coming weeks.

"We have reason to believe that the men could be working with Islamic State cells in other cities to attack civilians in one large event like the bombings in Paris in November 2015 or in smaller, coordinated events like the attacks in recent months like in Nice or in 
Brussels", said the representative of the Ministry of Justice.

\section{Difficult to prevent}

There are a growing number of warnings from top security officials about the threat of a terror attack in Norway in the coming months. Officials fear a recent call to arms by the Islamic State terror group may inspire a "lone wolf" attack. Lone wolf attacks are particularly hard for law enforcement to prevent and they can cause a great deal of destruction, says a representative of the Security Services and Policy Security Services to the newspaper.

The Ministry of Justice is urging local law enforcement to increase surveillance and take precautions during large public gatherings. - Military bases are on high alert and being fortified as well. Major cities like Oslo are increasingly utilizing nuclear detection devices to identify potential dirty bombs, says the representative.

The Ministry of Justice is asking citizens to be aware of their surroundings and immediately report suspicious individuals or packages to law enforcement when out in public.

The findings are of such a serious character that the authorities have chosen to inform the public, despite the danger of creating fear in the public.

The story will be updated as new information becomes available. 
Figure 7: Marginal effects of the targeted group by news story in different countries

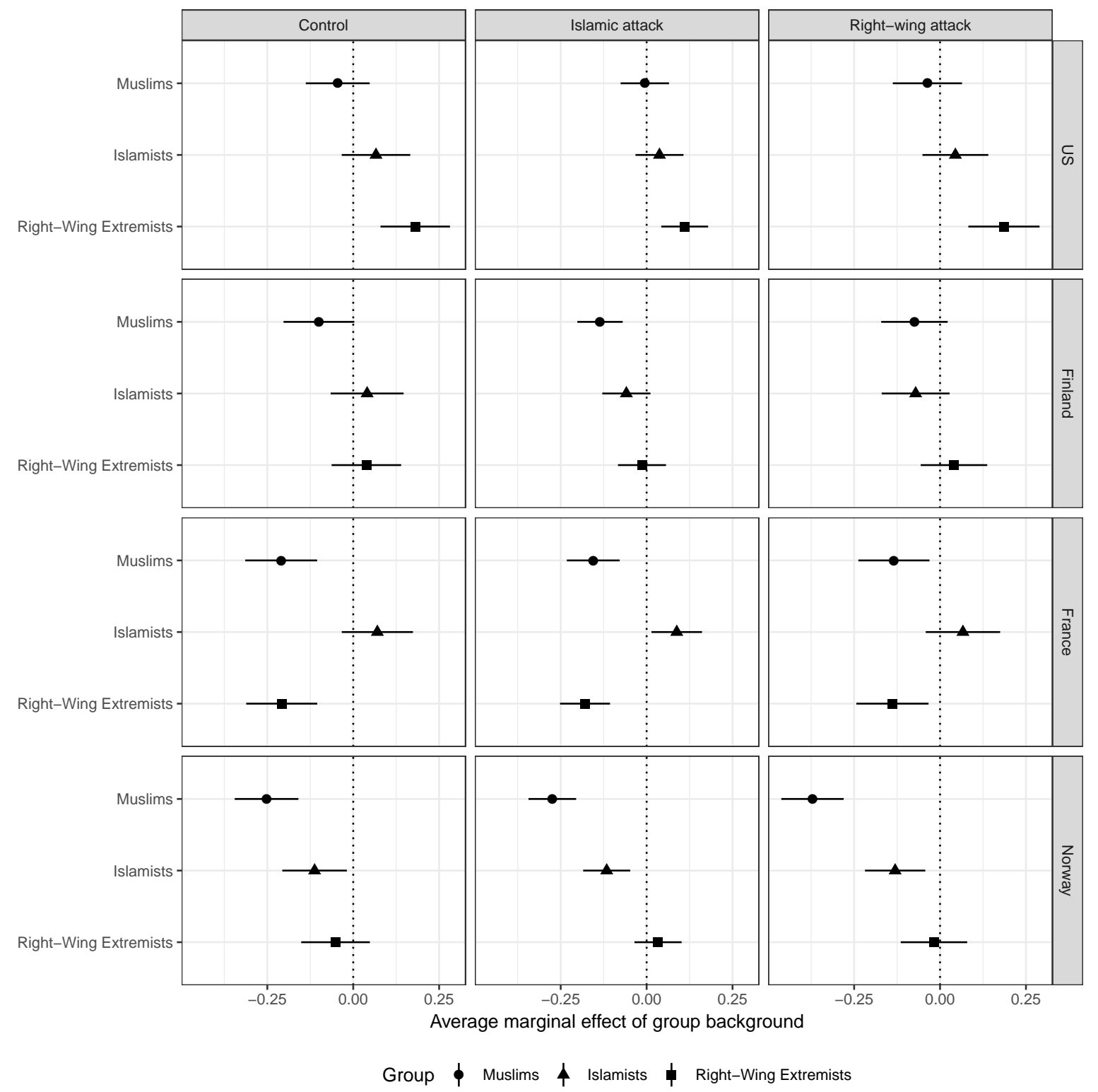




\section{Appendix: Tables and figures}

Table 3: Support for security measures

\begin{tabular}{|c|c|c|c|}
\hline & & curity index & \\
\hline & Model 1 & Model 2 & Model 3 \\
\hline Constant & $0.357^{* *}$ & $0.340^{* *}$ & $0.341^{* *}$ \\
\hline & $(0.031)$ & $(0.032)$ & $(0.034)$ \\
\hline CountryFinland & $0.105^{* *}$ & $0.105^{* *}$ & $0.104^{* *}$ \\
\hline & $(0.010)$ & $(0.010)$ & $(0.010)$ \\
\hline CountryFrance & $0.093^{* *}$ & $0.095^{* *}$ & $0.093^{* *}$ \\
\hline & $(0.010)$ & $(0.010)$ & $(0.010)$ \\
\hline CountryNorway & $0.031^{* *}$ & $0.031^{* *}$ & $0.031^{* *}$ \\
\hline & $(0.009)$ & $(0.010)$ & $(0.009)$ \\
\hline aget2 & $0.005^{* *}$ & $0.005^{* *}$ & $0.005^{* *}$ \\
\hline & $(0.001)$ & $(0.001)$ & $(0.001)$ \\
\hline$I($ aget2^2) & $-0.00004^{* *}$ & $-0.00005^{* *}$ & $-0.00004^{* *}$ \\
\hline & $(0.00001)$ & $(0.00001)$ & $(0.00001)$ \\
\hline education & $-0.021^{* *}$ & $-0.022^{* *}$ & $-0.020^{* *}$ \\
\hline & $(0.007)$ & $(0.007)$ & $(0.007)$ \\
\hline femalet2 & $-0.014^{*}$ & $-0.016^{*}$ & $-0.015^{*}$ \\
\hline & $(0.007)$ & $(0.007)$ & $(0.007)$ \\
\hline NewsIslamic attack & $0.035^{* *}$ & $0.045^{* *}$ & $0.054^{*}$ \\
\hline & $(0.008)$ & $(0.012)$ & $(0.022)$ \\
\hline NewsRight-wing attack & $0.027^{* *}$ & $0.041^{* *}$ & $0.054^{*}$ \\
\hline & $(0.009)$ & $(0.013)$ & $(0.025)$ \\
\hline ethnicIndex_cent & $0.463^{* *}$ & $0.457^{* *}$ & $0.432^{* *}$ \\
\hline & $(0.024)$ & $(0.026)$ & $(0.048)$ \\
\hline GroupMuslims & $-0.154^{* *}$ & $-0.129^{* *}$ & $-0.153^{* *}$ \\
\hline & $(0.013)$ & $(0.010)$ & $(0.025)$ \\
\hline GroupIslamists & -0.019 & -0.004 & 0.009 \\
\hline & $(0.013)$ & $(0.010)$ & $(0.026)$ \\
\hline GroupRight-Wing Extremists & 0.002 & -0.010 & -0.0002 \\
\hline & $(0.013)$ & $(0.010)$ & $(0.026)$ \\
\hline I(ethnicIndex_cent $\left.{ }^{\wedge} 2\right)$ & $-0.267^{* *}$ & -0.087 & -0.130 \\
\hline & $(0.084)$ & $(0.088)$ & $(0.166)$ \\
\hline ethnicIndex_cent:GroupMuslims & $0.276^{* *}$ & & $0.289^{* *}$ \\
\hline & $(0.034)$ & & $(0.069)$ \\
\hline ethnicIndex_cent:GroupIslamists & $0.206^{* *}$ & & $0.190^{* *}$ \\
\hline & $(0.034)$ & & $(0.069)$ \\
\hline ethnicIndex_cent:GroupRight-Wing Extremists & $-0.330^{* *}$ & & $-0.355^{* *}$ \\
\hline & $(0.035)$ & & $(0.069)$ \\
\hline NewsIslamic attack:GroupMuslims & & & 0.004 \\
\hline & & & $(0.031)$ \\
\hline NewsRight-wing attack:GroupMuslims & & & -0.011 \\
\hline & & & $(0.036)$ \\
\hline NewsIslamic attack:GroupIslamists & & & -0.032 \\
\hline
\end{tabular}


Figure 8: Predicted support for security measures by groups

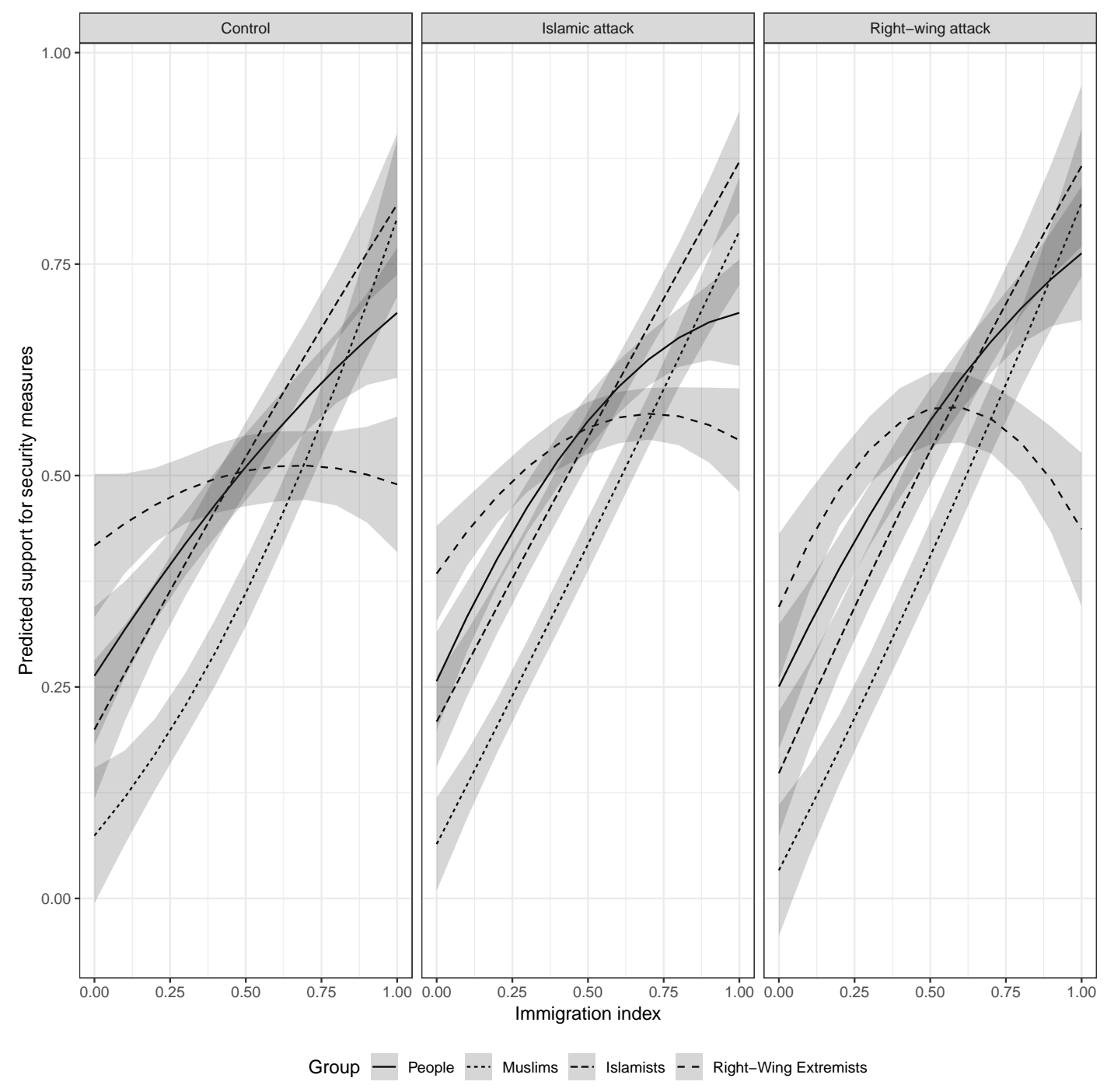


Figure 9: Predicted support for security measures by group and country

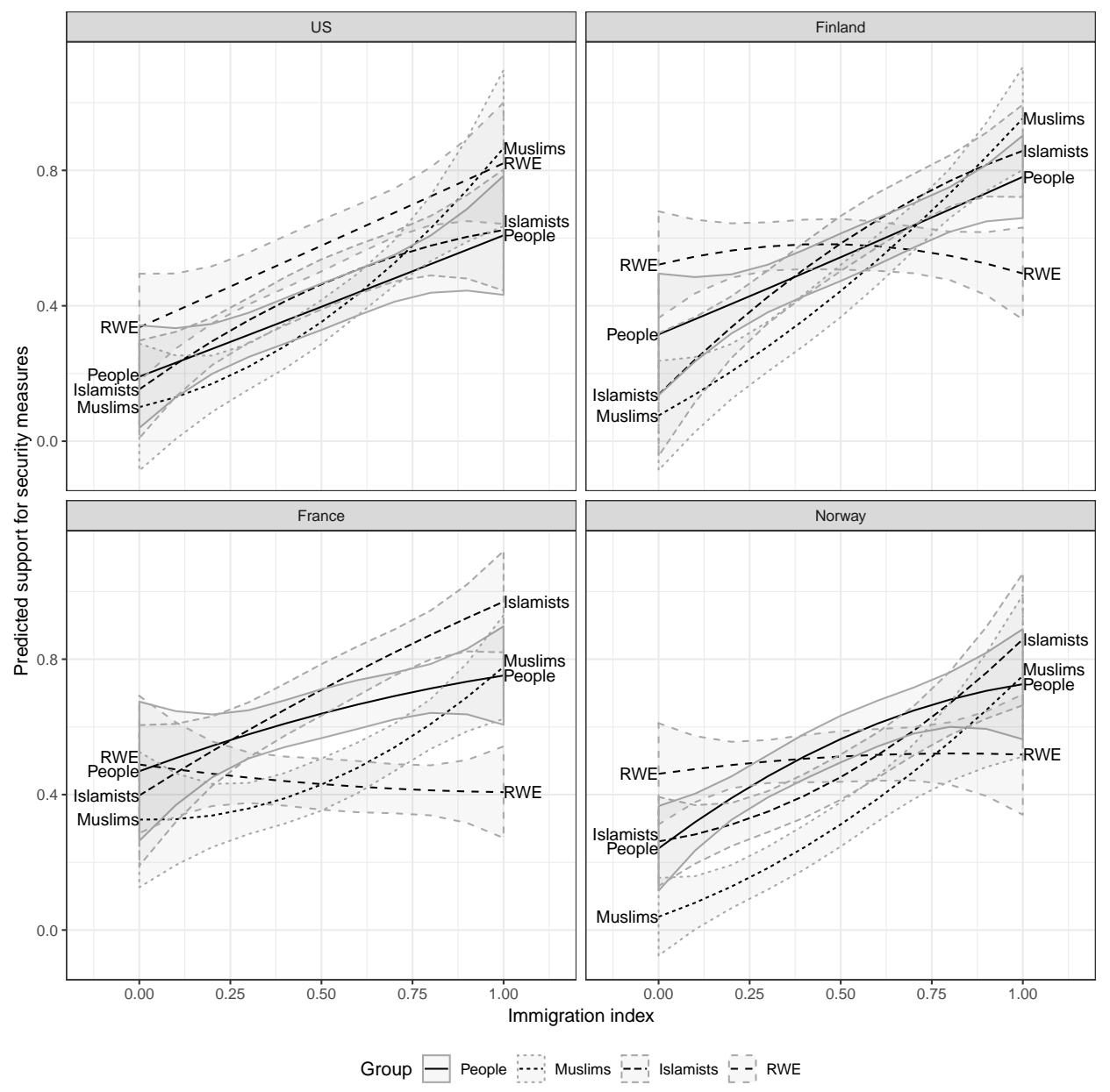


Figure 10: Balance in the news groups

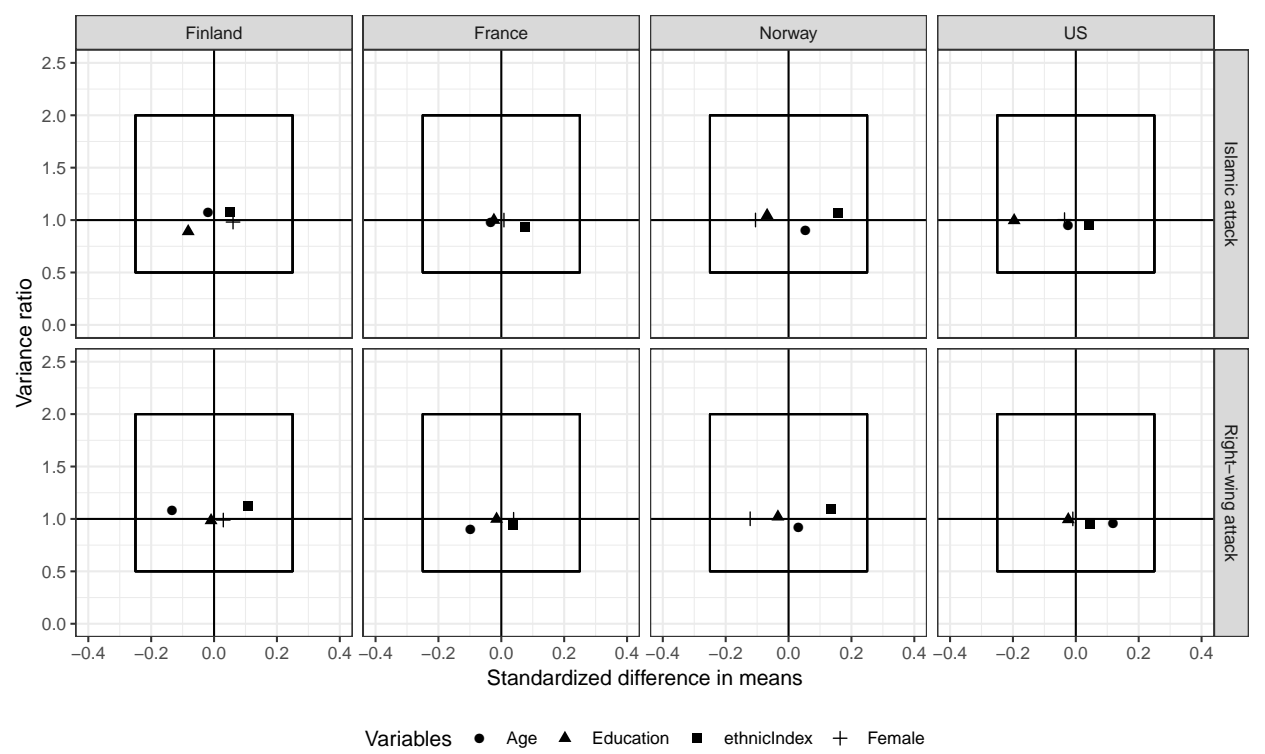


Figure 11: Balance in the target groups

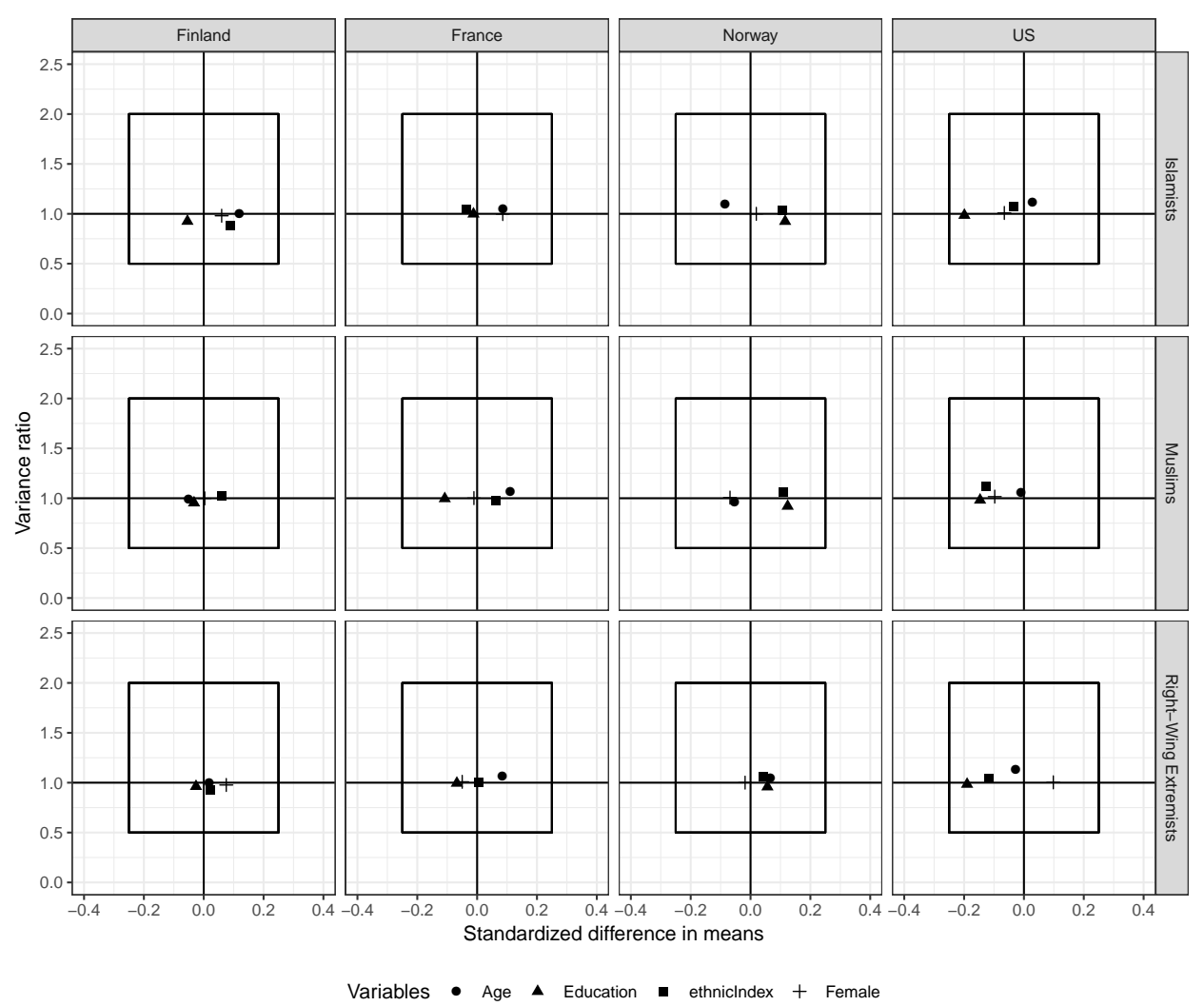


Table 4: Descriptive statistics news experiment (standard deviation in parenhteses)

\begin{tabular}{|c|c|c|c|c|}
\hline Country & Variable & Control & Islamic attack & Right-wing attack \\
\hline Norway & $\mathrm{N}$ & 476 & 971 & 504 \\
\hline Norway & Age & 52.5 & 51.7 & 52 \\
\hline Norway & & $(15.9)$ & $(16.7)$ & $(16.6)$ \\
\hline Norway & Education & 0.634 & 0.667 & 0.651 \\
\hline Norway & & $(0.482)$ & $(0.471)$ & $(0.477)$ \\
\hline Norway & Immigration attitudes & 0.418 & 0.377 & 0.383 \\
\hline Norway & & $(0.262)$ & $(0.254)$ & $(0.25)$ \\
\hline Norway & Female & 0.473 & 0.525 & 0.534 \\
\hline Norway & & $(0.5)$ & $(0.5)$ & $(0.499)$ \\
\hline Finland & $\mathrm{N}$ & 450 & 954 & 468 \\
\hline Finland & Age & 50.2 & 50.6 & 52.5 \\
\hline Finland & & $(17.1)$ & $(16.6)$ & $(16.5)$ \\
\hline Finland & Education & 0.191 & 0.224 & 0.195 \\
\hline Finland & & $(0.394)$ & $(0.417)$ & $(0.397)$ \\
\hline Finland & Immigration attitudes & 0.55 & 0.536 & 0.52 \\
\hline Finland & & $(0.282)$ & $(0.272)$ & $(0.266)$ \\
\hline Finland & Female & 0.598 & 0.568 & 0.583 \\
\hline Finland & & $(0.491)$ & $(0.496)$ & $(0.494)$ \\
\hline France & $\mathrm{N}$ & 458 & 893 & 454 \\
\hline France & Age & 45.2 & 45.7 & 46.6 \\
\hline France & & $(14.5)$ & $(14.6)$ & $(15.3)$ \\
\hline France & Education & 0.48 & 0.492 & 0.488 \\
\hline France & & $(0.5)$ & $(0.5)$ & $(0.5)$ \\
\hline France & Immigration attitudes & 0.561 & 0.541 & 0.551 \\
\hline France & & $(0.265)$ & $(0.275)$ & $(0.273)$ \\
\hline France & Female & 0.533 & 0.529 & 0.513 \\
\hline France & & $(0.499)$ & $(0.499)$ & $(0.5)$ \\
\hline US & $\mathrm{N}$ & 461 & 983 & 451 \\
\hline US & Age & 45.9 & 46.3 & 43.9 \\
\hline US & & $(16.5)$ & $(16.9)$ & $(16.8)$ \\
\hline US & Education & 0.446 & 0.543 & 0.458 \\
\hline US & & $(0.498)$ & $(0.498)$ & $(0.499)$ \\
\hline US & Immigration attitudes & 0.483 & 0.472 & 0.471 \\
\hline US & & $(0.257)$ & $(0.263)$ & $(0.263)$ \\
\hline US & Female & 0.514 & 0.532 & 0.519 \\
\hline US & & $(0.5)$ & $(0.499)$ & $(0.5)$ \\
\hline
\end{tabular}


Table 5: Descriptive statistics group experiment (standard deviation in parenhteses)

\begin{tabular}{|c|c|c|c|c|c|}
\hline Country & Variable & People & Muslims & Islamists & Right-Wing Extremists \\
\hline Norway & $\mathrm{N}$ & 521 & 475 & 513 & 442 \\
\hline Norway & Age & 51.6 & 52.5 & 53.1 & 50.5 \\
\hline Norway & & $(16.7)$ & $(17)$ & $(15.9)$ & $(16.3)$ \\
\hline Norway & Education & 0.689 & 0.632 & 0.635 & 0.663 \\
\hline Norway & & $(0.463)$ & $(0.483)$ & $(0.482)$ & $(0.473)$ \\
\hline Norway & Immigration attitudes & 0.405 & 0.377 & 0.378 & 0.394 \\
\hline Norway & & $(0.26)$ & $(0.252)$ & $(0.255)$ & $(0.252)$ \\
\hline Norway & Female & 0.507 & 0.541 & 0.497 & 0.516 \\
\hline Norway & & $(0.5)$ & $(0.499)$ & $(0.5)$ & $(0.5)$ \\
\hline Finland & $\mathrm{N}$ & 482 & 480 & 447 & 462 \\
\hline Finland & Age & 51.3 & 52.2 & 49.3 & 51 \\
\hline Finland & & $(16.7)$ & $(16.8)$ & $(16.6)$ & $(16.7)$ \\
\hline Finland & Education & 0.198 & 0.21 & 0.219 & 0.208 \\
\hline Finland & & $(0.399)$ & $(0.408)$ & $(0.414)$ & $(0.406)$ \\
\hline Finland & Immigration attitudes & 0.546 & 0.53 & 0.523 & 0.541 \\
\hline Finland & & $(0.267)$ & $(0.264)$ & $(0.285)$ & $(0.277)$ \\
\hline Finland & Female & 0.595 & 0.594 & 0.566 & 0.558 \\
\hline Finland & & $(0.491)$ & $(0.492)$ & $(0.496)$ & $(0.497)$ \\
\hline France & $\mathrm{N}$ & 420 & 442 & 457 & 486 \\
\hline France & Age & 46.9 & 45.2 & 45.6 & 45.6 \\
\hline France & & $(15.1)$ & $(14.6)$ & $(14.7)$ & $(14.6)$ \\
\hline France & Education & 0.464 & 0.518 & 0.47 & 0.498 \\
\hline France & & $(0.499)$ & $(0.5)$ & $(0.5)$ & $(0.501)$ \\
\hline France & Immigration attitudes & 0.551 & 0.533 & 0.56 & 0.549 \\
\hline France & & $(0.273)$ & $(0.276)$ & $(0.267)$ & $(0.272)$ \\
\hline France & Female & 0.529 & 0.534 & 0.486 & 0.553 \\
\hline France & & $(0.5)$ & $(0.499)$ & $(0.5)$ & $(0.498)$ \\
\hline US & $\mathrm{N}$ & 467 & 478 & 481 & 469 \\
\hline US & Age & 45.6 & 45.7 & 45.1 & 46.1 \\
\hline US & & $(17.4)$ & $(16.9)$ & $(16.5)$ & $(16.4)$ \\
\hline US & Education & 0.433 & 0.505 & 0.531 & 0.527 \\
\hline US & & $(0.496)$ & $(0.5)$ & $(0.5)$ & $(0.5)$ \\
\hline US & Immigration attitudes & 0.455 & 0.49 & 0.465 & 0.487 \\
\hline US & & $(0.269)$ & $(0.254)$ & $(0.26)$ & $(0.264)$ \\
\hline US & Female & 0.516 & 0.565 & 0.549 & 0.467 \\
\hline US & & $(0.5)$ & $(0.496)$ & $(0.498)$ & $(0.499)$ \\
\hline
\end{tabular}

